\title{
低強度コンクリートの既存 SRC 部材のせん断終局強度 ULTIMATE SHEAR STRENGTH OF EXISTING STEEL REINFORCED CONCRETE MEMBERS WITH LOW-STRENGTH CONCRETE
}

\author{
チューチューヌエ*1, 貞末和史*2, 荒木秀夫*3 \\ KJU KJU NWE, Kazushi SADASUE and Hideo ARAKI
}

\begin{abstract}
In this paper, shear strength of SRC members with low-strength concrete were investigated through the seismic loading tests. According to the experimental results, regardless of concrete strength and type of steel frame, shear-bond cracks were occurred along the steel flange position of members, when reaching the maximum strength. The ultimate shear strength for those low-strength concrete members have not been established clearly in the existing evaluation method recommended by JBDPA. Thus, we propose an evaluation method of the ultimate shear strength of SRC members and it is confirmed, the proposed method can be appropriately evaluated more than existing method.
\end{abstract}

Keywords : Low-strength concrete, Steel reinforced concrete structure, Seismic evaluation, Ultimate shear strength, Shear bond failure 低強度コンクリート, 鉄骨鉄筋コンクリート構造, 而震診断, せん断終局強度, せん断付着破壊

1. はじめに

1995 年に制定された「建築物の耐震改修の促進に関する法律」を 受け, 1981 年の建築基準法改正以前に造られた公立学校等建物に対 しては耐震診断と耐震補強が積極的に行なわれたが，民間建物に目 を向けると戦後復興期に造られた建築が既存不適格構造物として数 多く残されている。そのような状沉の中, コンクリート系建物の重 要な問題として，コンクリートの圧縮強度が極めて低い既存建物が 存在し，その建物の耐震診断と耐震改修をどのように行い評価する かということが顕在化している。コンクリートは建築および土木構 造物における主要な材料として多用されてきたが，コンクリートの 性能は設計と施工の精度に敏感であり, 調合設計や練混ぜ・打込み の知識と技術が未熟で品質管理が不十分であった時代に造られた学 校建築等の既存建物では低強度のコンクリートが見つかったため, 低強度コンクリートを有する鉄筋コンクリート (以後, $\mathrm{RC}$ と称す) 構造については耐震性能に関する組織的な研究が行なわれた ${ }^{11}$ 。

一方で, 不特定多数の人々が利用する病院・旅館や避難弱者が利 用寸る大規模建物に関して耐震診断を義務付ける「改正建築物の耐 震改修の促進に関する法律」が 2013 年に施行され, これらの建物 の耐震性を向上させる必要性が法令として示された 2)。鉄骨鉄筋コ ンクリート (以後, SRC と称す) 構造の新規採用は減少傾向にあるも のの, 既存の 6 9 階程度の建物では SRC 構造が多く採用されてお り 3), 鉄骨の存在によりコンクリートの充填が難しい SRC 構造にも $\mathrm{RC}$ 構造と同様に低強度コンクリートの既存建物が存在している可
能性がある。

本研究では SRC 構造を対象として, 日本建築防災協会の既存 $\mathrm{SRC}$ 造建築物の耐震診断基準 ${ }^{4}$ (以後, SRC 而震診断基準と称す) におけるコンクリート圧縮強度 $\sigma_{B}$ の適用範囲 $\left(\sigma_{B} \geqq 13.5 \mathrm{~N} / \mathrm{mm}^{2}\right)$ を 下回る低強度コンクリートの $\mathrm{SRC}$ 柱と $\mathrm{SRC}$ 梁の載荷実験を行ない, 曲げ破壊に対してせん断破壊が先行する SRC 部材の破壊性状と履 歴特性について明らかにする。また, 低強度コンクリートに対応で きる SRC 部材のせん断終局強度の評価式を提案する。

\section{2. 実験概要}

\section{1 柱試験体}

柱試験体の一覧を Table1, 試験体形状の一例を Fig.1 にそれぞれ 示す。いずれの試験体とも曲げ破壊に対してせん断破壊が先行する ことを想定した SRC 柱として計画し, コンクリート強度, 鉄骨の 形式 (充腹型, 非充腹型) と形状 (十字形, $\mathrm{H}$ 形), せん断スパン比お よび軸力比を変数とした合計 14 体の SRC 柱を製作した。

全試験体の柱断面は $300 \mathrm{~mm} \times 300 \mathrm{~mm}$ ，内法長さは $900 \mathrm{~mm}$ およ び $600 \mathrm{~mm}$ とした。コンクリートの目標圧縮強度 $F_{c}$ は $18 \mathrm{~N} / \mathrm{mm}^{2}$ と $9 \mathrm{~N} / \mathrm{mm}^{2}$ の 2 種類とした。コンクリートの調合を Table 2 に示す。 1975 年に改定された SRC 規準・第 3 版 5)では充腹型鉄骨を用いる ことが推奨されているため, これ以後に建設された建物では充腹型 の鉄骨と異形棒鋼の主筋が使われた SRC 構造が大半を占めると思 われる。そこで，充腹型 SRC 柱の鉄骨は全て H-200×100×5.5×8

\footnotetext{
*1 広島工業大学大学院工学系研究科知的機能科学専攻 博士後期課程 · 修士 (工学)

*2 広島工業大学工学部建築工学科 准教授·博士 (工学)

*3 広島工業大学工学部建築工学科 教授. 工博
}

Grad. Student, Major in Intelligent Structure and Functional Science, Hiroshima Institute of Technology, M.Eng

Assoc. Prof., Dept. of Architectural Eng., Faculty of Eng., Hiroshima Institute of Technology, Dr.Eng.

Prof., Dept. of Architectural Eng., Faculty of Eng., Hiroshima Institute of Technology, Dr.Eng. 
Table 1 List of test column

\begin{tabular}{|c|c|c|c|c|c|c|c|c|c|c|c|c|c|}
\hline Specimen & $\begin{array}{c}\text { Steel } \\
\text { type }\end{array}$ & $\begin{array}{r}\text { Steel } \\
\text { shape }\end{array}$ & $\begin{array}{c}F_{c} \\
\left(\mathrm{~N} / \mathrm{mm}^{2}\right)\end{array}$ & Main steel & Tie plate & Main rebar & Hoop & $\frac{M}{Q \cdot d}$ & $\begin{array}{c}1 \\
(\mathrm{~mm})\end{array}$ & $b^{\prime} / b$ & $\begin{array}{c}N \\
(\mathrm{kN})\end{array}$ & $n$ & $\begin{array}{l}\text { Test } \\
\text { series }\end{array}$ \\
\hline C18FC1515 & \multirow{6}{*}{$\begin{array}{l}\text { Full } \\
\text { web }\end{array}$} & \multirow{4}{*}{ Cross } & 18 & \multirow{4}{*}{$\begin{array}{c}2 \mathrm{H}-200 \times 100 \times 5.5 \times 8 \\
\quad\left(s p_{t}=0.89 \%\right)\end{array}$} & & \multirow{6}{*}{$\begin{array}{c}12-\mathrm{D} 13 \\
\left(\begin{array}{c}\left.p_{t}=0.84 \%\right)\end{array}\right)\end{array}$} & $\mathrm{D} 6 @ 100\left(p_{W}=0.21 \%\right)$ & \multirow{3}{*}{1.5} & \multirow{3}{*}{900} & \multirow{4}{*}{0.33} & 1095 & 0.28 & I \\
\hline C09FC1530 & & & 9 & & & & $\phi 6 @ 100\left(p_{W}=0.19 \%\right)$ & & & & 1129 & 0.30 & II \\
\hline C09FC1515 & & & & & & & & & & & 994 & 0.27 & \multirow{2}{*}{ III } \\
\hline$\frac{\mathrm{C} 18 \mathrm{FC} 1015}{\mathrm{C} 09 \mathrm{FC} 1030}$ & & & $\frac{18}{9}$ & & & & \multirow{3}{*}{$\mathrm{D} 6 @ 100\left(p_{W}=0.21 \%\right)$} & 1.0 & 600 & & $\frac{1094}{1172}$ & 0.28 & \\
\hline $\begin{array}{l}\text { C09FC1030 } \\
\text { C18FH1515 }\end{array}$ & & \multirow{2}{*}{$\mathrm{H}$} & 18 & $\mathrm{H}-200 \times 100 \times 5.5 \times 8$ & & & & & & & $\frac{1172}{766}$ & \begin{tabular}{|l}
0.36 \\
0.20
\end{tabular} & \\
\hline C09FH1530 & & & 9 & $(n+=089 \%)$ & & & & 1.5 & 900 & 0.67 & 699 & 0.30 & IV \\
\hline $\mathrm{C} 18 \mathrm{BC} 1515$ & \multirow{6}{*}{$\begin{array}{l}\text { Open } \\
\text { web }\end{array}$} & \multirow{4}{*}{ Cross } & 18 & \multirow{4}{*}{$\begin{array}{l}8 \mathrm{~L}^{-}-50 \times 50 \times 6 \\
\left(p_{t} p_{t}=1.25 \%\right)\end{array}$} & \multirow{6}{*}{$\begin{array}{l}\text { PL6-30@200 } \\
\left(s p_{w}=0.30 \%\right)\end{array}$} & \multirow{6}{*}{$\begin{array}{c}12-\phi 13 \\
\left(\begin{array}{c}\left.p_{t}=0.87 \%\right)\end{array}\right)\end{array}$} & $\mathrm{D} 6 @ 100\left(p_{w}=0.21 \%\right)$ & \multirow[b]{2}{*}{1.5} & \multirow[b]{2}{*}{900} & \multirow{4}{*}{0.33} & 947 & 0.27 & $\mathrm{I}$ \\
\hline C09BC1530 & & & 9 & & & & $\phi 6 @ 100\left(p_{W}=0.19 \%\right)$ & & & & 956 & $\frac{0.33}{0.28}$ & II \\
\hline$\frac{\text { C09BC1515 }}{\text { C18BC1015 }}$ & & & 18 & & & & \multirow{4}{*}{$\mathrm{D} 6 @ 100\left(p_{W}=0.21 \%\right)$} & \multirow{2}{*}{1.0} & \multirow{2}{*}{600} & & $\begin{array}{l}021 \\
982\end{array}$ & $\begin{array}{l}0.20 \\
0.27\end{array}$ & \multirow{2}{*}{ III } \\
\hline C09BC1030 & & & $\frac{x}{9}$ & & & & & & & & 1046 & 0.34 & \\
\hline C18BH1515 & & & 18 & $4 \mathrm{~L}^{-}-50 \times 50 \times 6$ & & & & 1.5 & 900 & 0.65 & 721 & 0.20 & IV \\
\hline C09BH1530 & & & 9 & $\left(s p_{t}=0.89 \%\right)$ & & & & & & & 655 & 0.32 & \\
\hline
\end{tabular}

$s p_{t}$ :Tension steel ratio, $s p_{W}$ :Tie plate ratio, $r p_{t}$ :Tension reinforcement ratio, $p_{W}$ : Shear reinforcement ratio, $M /(Q \cdot d)$ : Shear span ratio, $I:$ Inside measurement of member, $b^{\prime}:$ Effective width of concrete $(=b-f b), b$ :Column width, $f b$ : Frange width, $N:$ Axial load,

$n$ :Axial load ratio $\left(=N / N_{u}\right), N_{u}$ : Axial strength of SRC column

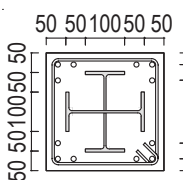

$30|4016040| 30$.

C18FC1515 C09FC1530

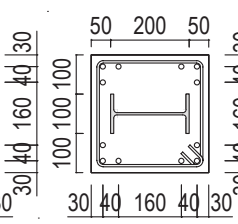

C18FH1515 C09FH1530

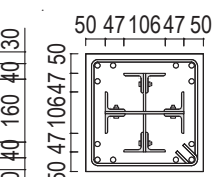

30 4d $16040130^{\circ}$

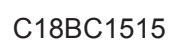
С09BC1530

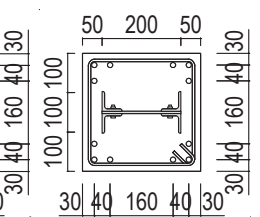

C18BH1515 $\mathrm{C} 09 \mathrm{BH} 1530$

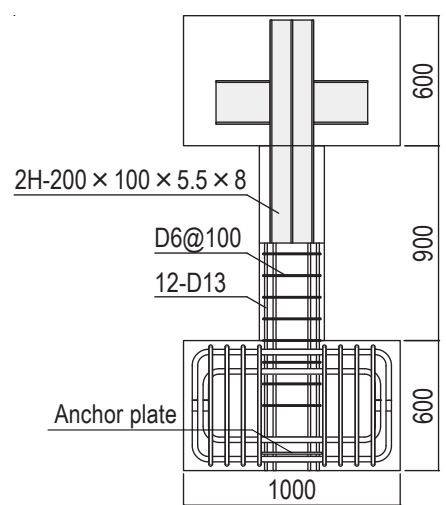

C18FC1515, C09FC1530

(a) Full web type

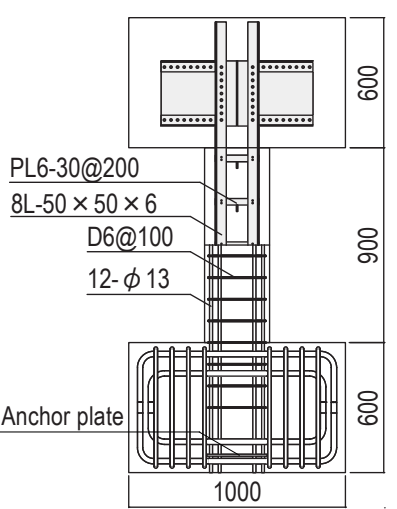

C18BC1515, C09BC1530

(b) Open web type
Fig.1 Details of test columns (unit:mm)

の $\mathrm{H}$ 形鋼，主筋は 12-D13 を用いた。なお，試験体製作時における 材料の入手の都合により, せん断補強筋は D 6 と $\phi 6$ を用いている が, せん断補強筋については異形棒鋼と丸鋼の違いが実験結果に与 える影響は小さいと考えている。

一方，1975 年以前に建設された SRC 構造には非充腹型の鉄骨と 丸鋼の主筋が使われていると思われるため, 非充腹型 SRC 柱の鉄 骨は全て L-50×50×6 の山形鋼と PL6-30 の帯板を用いて格子形に 組み立て, 主筋は $12^{-} \phi 13$, せん断補強筋は D6 あるいは $\phi 6$ を用 いた。なお，想定した年代の建物では山形鋼と帯板の接合はリベッ トが用いられているが，現在は製作が困難であるため，本試験体で は 2-M6（孔径 $\phi 7$ ) の六角穴付きボルトを用いて組み立てた。

試験体に用いたコンクリートおよび鋼材の材料試験結果一覧を Table3, Table4, コンクリートの応力度-ひずみ度関係の一例を
Table 2 Mix proportion of concrete

\begin{tabular}{c|c|c|c|c|c|c|c}
\hline$F_{c}$ & $\begin{array}{c}\text { Water } \\
\left(\mathrm{kg} / \mathrm{m}^{3}\right)\end{array}$ & $\begin{array}{c}\text { Cement } \\
\left(\mathrm{kg} / \mathrm{m}^{3}\right)\end{array}$ & $\begin{array}{c}\text { Fine } \\
\text { aggregate } \\
\left(\mathrm{kg} / \mathrm{m}^{3}\right)\end{array}$ & $\begin{array}{c}\text { Coarse } \\
\text { aggregate } \\
\left(\mathrm{kg} / \mathrm{m}^{3}\right)\end{array}$ & $\begin{array}{c}\text { Admixture } \\
\left(\mathrm{kg} / \mathrm{m}^{3}\right)\end{array}$ & $\begin{array}{c}\text { Water } \\
\text { cement } \\
\text { ratio } \\
(\%)\end{array}$ & $\begin{array}{c}\text { Fine } \\
\text { aggregate } \\
\text { ratio } \\
(\%)\end{array}$ \\
\hline 18 & 194 & 244 & 1001 & 818 & 1.76 & 79.5 & 55.8 \\
9 & 197 & 179 & 1058 & 806 & 1.29 & 110 & 57.3 \\
\hline
\end{tabular}

Table 3 Mechanical properties of concrete

\begin{tabular}{|c|c|c|c|c|}
\hline Specimen & $\begin{array}{c}F_{c} \\
\left(\mathrm{~N} / \mathrm{mm}^{2}\right)\end{array}$ & $\begin{array}{c}\sigma_{B} \\
\left(\mathrm{~N} / \mathrm{mm}^{2}\right)\end{array}$ & $\begin{array}{c}\sigma_{t} \\
\left(\mathrm{~N} / \mathrm{mm}^{2}\right)\end{array}$ & $\begin{array}{c}E \\
\left(\mathrm{~N} / \mathrm{mm}^{2}\right)\end{array}$ \\
\hline C18FC1515 & 18 & 19.1 & 2.01 & 27707 \\
\hline $\begin{array}{l}\text { C09FC1530 } \\
\text { C09FC1515 }\end{array}$ & 9 & 10.3 & 1.35 & 20407 \\
\hline $\mathrm{C} 18 \mathrm{FC} 1015$ & 18 & 19.3 & 1.86 & 25159 \\
\hline C09FC1030 & 9 & 12.4 & 1.36 & 19549 \\
\hline C18FH1515 & 18 & 26.3 & 2.07 & 27197 \\
\hline C09FH1530 & 9 & 10.7 & 1.17 & 16608 \\
\hline C18BC1515 & 18 & 18.3 & 1.98 & 27534 \\
\hline $\begin{array}{l}\text { C09BC1530 } \\
\text { C09BC1515 }\end{array}$ & 9 & 10.6 & 1.36 & 19157 \\
\hline C18BC1015 & 18 & 18.9 & 2.07 & 26601 \\
\hline C09BC1030 & 9 & 12.1 & 1.35 & 21809 \\
\hline C18BH1515 & 18 & 26.1 & 2.30 & 29010 \\
\hline C09BH1530 & 9 & 9.5 & 1.15 & 16608 \\
\hline
\end{tabular}

$\sigma_{B}$ :Compressive strength, $\sigma_{t}$ : Cleavage strength,

$E$ :Young's modulus

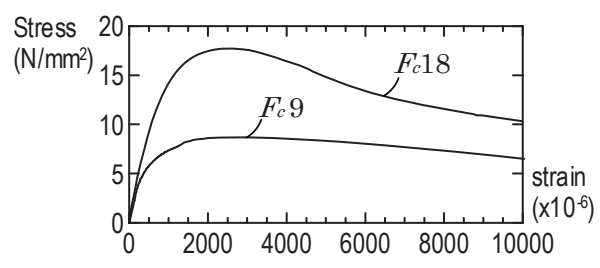

Fig.2 Stress-strain curves of concrete

Fig. 2 にそれぞれ示す。 $F_{c} 18$ のコンクリートと比べて,$F_{c} 9$ のコン クリートは，軟化域における強度低下が非常にゆるやかであること が特徵的である。本論で示す低強度コンクリートは, ジャンカ等の 不具合によって所要の強度が得られないコンクリートではなく，何 れかの理由で水セメント比が高くなっていたり，劣化したセメント が使われていたことの影響 1)で, Fig.2 に示されるような材料特性を 有している低強度コンクリートを対象とする。

圧縮軸力 $N$ に関して, $F_{c} 18$ の試験体は, $N=0.15_{c} N_{u}+0.5_{s} N_{u}$ (ここ 
Table 4 Mechanical properties of steel

\begin{tabular}{|c|c|c|c|c|c|c|c|c|c|c|c|c|}
\hline \multirow[b]{2}{*}{ Steel } & \multicolumn{3}{|c|}{ Test series I } & \multicolumn{3}{|c|}{ Test series II } & \multicolumn{3}{|c|}{ Test series III } & \multicolumn{3}{|c|}{ Test series IV } \\
\hline & $\begin{array}{c}\sigma_{y} \\
\left(\mathrm{~N} / \mathrm{mm}^{2}\right)\end{array}$ & $\begin{array}{c}\sigma u \\
\left(\mathrm{~N} / \mathrm{mm}^{2}\right)\end{array}$ & $\begin{array}{c}\text { Elongation } \\
(\%)\end{array}$ & $\begin{array}{c}\sigma y \\
\left(\mathrm{~N} / \mathrm{mm}^{2}\right)\end{array}$ & $\begin{array}{c}\sigma u \\
\left(\mathrm{~N} / \mathrm{mm}^{2}\right)\end{array}$ & \begin{tabular}{|c|} 
Elongation \\
$(\%)$
\end{tabular} & $\begin{array}{c}\sigma_{y} \\
\left(\mathrm{~N} / \mathrm{mm}^{2}\right)\end{array}$ & $\begin{array}{c}\sigma u \\
\left(\mathrm{~N} / \mathrm{mm}^{2}\right)\end{array}$ & \begin{tabular}{|c|}
$\begin{array}{c}\text { Elongation } \\
(\%)\end{array}$ \\
\end{tabular} & $\begin{array}{c}\sigma y \\
\left(\mathrm{~N} / \mathrm{mm}^{2}\right)\end{array}$ & $\begin{array}{c}\sigma u \\
\left(\mathrm{~N} / \mathrm{mm}^{2}\right)\end{array}$ & $\begin{array}{c}\text { Elongation } \\
(\%)\end{array}$ \\
\hline Flange & 321 & 448 & 19.4 & 326 & 450 & 25.0 & 321 & 448 & \begin{tabular}{|l|}
19.4 \\
\end{tabular} & 307 & 422 & 25.5 \\
\hline Web & 307 & 435 & 21.4 & 347 & 464 & 23.2 & 307 & 435 & 21.4 & 312 & 433 & 23.9 \\
\hline Angle & 310 & 446 & 19.1 & 322 & 467 & 25.7 & 322 & 467 & 25.7 & 324 & 465 & 23.3 \\
\hline Tie plate & 269 & 360 & 30.3 & 269 & 360 & 30.3 & 269 & 360 & 30.3 & 269 & 360 & 30.3 \\
\hline Main rebar D13 & 330 & 470 & 18.4 & 366 & 520 & 21.1 & 330 & 470 & 18.4 & 366 & 519 & 21.1 \\
\hline Main rebar $\phi 13$ & 307 & 430 & 26.0 & 301 & 417 & 34.2 & 307 & 430 & 26.0 & 305 & 438 & 29.7 \\
\hline Hoop & 346 & 524 & 20.9 & 379 & 542 & 18.6 & 346 & 524 & 20.9 & 311 & 464 & 19.0 \\
\hline
\end{tabular}

$\sigma_{y}:$ Yeild strength, $\sigma_{u}:$ Tensile strength

Table 5 List of test beam

\begin{tabular}{|c|c|c|c|c|c|c|c|c|c|c|}
\hline Specimen & Steel type & Steel shape & $\begin{array}{c}F_{c} \\
\left(\mathrm{~N} / \mathrm{mm}^{2}\right)\end{array}$ & Main steel & Tie plate & Main rebar & Stirrup & $\frac{M}{Q \cdot d}$ & $\begin{array}{c}1 \\
(\mathrm{~mm})\end{array}$ & $b^{\prime} / b$ \\
\hline B182032 & \multirow{5}{*}{ Open web } & \multirow{5}{*}{$\mathrm{H}$} & \multirow[b]{2}{*}{18} & \multirow{2}{*}{$4 \mathrm{~L}-65 \times 65 \times 6(s p t=1.88 \%)$} & \multirow{5}{*}{$\begin{array}{l}\text { PL6-30@200 } \\
\left(s p_{w}=0.43 \%\right)\end{array}$} & \multirow{5}{*}{$\left(\begin{array}{c}6^{-} \phi 16 \\
(r p t=0.90 \%)\end{array}\right.$} & $\mathrm{D} 6 @ 160\left(p_{w}=0.20 \%\right)$ & \multirow{5}{*}{2.0} & \multirow{5}{*}{1600} & ר 2 \\
\hline B183232 & & & & & & & & & & 0.32 \\
\hline B092032 & & & \multirow{3}{*}{9} & \multirow[t]{2}{*}{$4 \mathrm{~L}-65 \times 65 \times 6\left(s_{p} p_{t}=1.88 \%\right)$} & & & $\mathrm{D} 6 @ 160\left(p_{W}=0.20 \%\right)$ & & & 0.32 \\
\hline B093232 & & & & & & & D6@100 $\left(p_{W}=0.32 \%\right)$ & & & \\
\hline B093257 & & & & $4 \mathrm{~L}-65 \times 45 \times 6\left(s p_{t}=1.49 \%\right)$ & & & & & & 0.57 \\
\hline
\end{tabular}

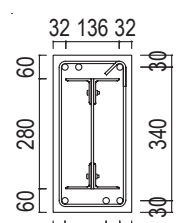

30| $|105 \$ 5| 30$

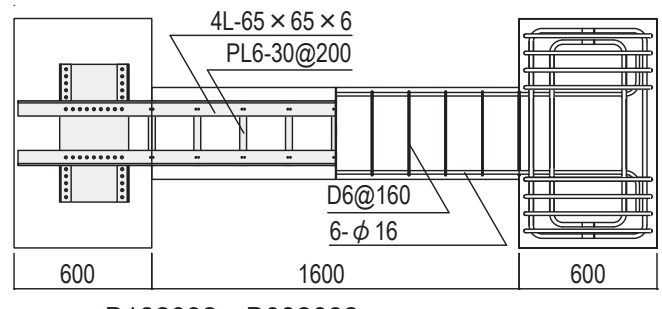

B182032, B092032

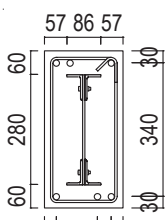

30|| $10535 \mid 30$

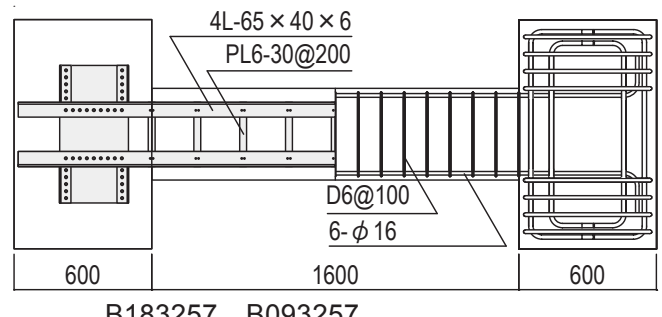

Fig.3 Details of test beams (unit:mm)

に, ${ }_{c} N_{u}$ はコンクリート部分の圧縮耐力, ${ }_{s} N_{u}$ は鉄骨部分の圧縮耐力） を設計時に想定された SRC 建物の柱軸力として設定した。F $F_{c} 9$ の試 験体は, $F_{c} 18$ で $N=0.15{ }_{c} N_{u}+0.5{ }_{s} N_{u}$ で設計された柱に対して, 実際 のコンクリート圧縮強度 $\sigma_{B}$ が $9 \mathrm{~N} / \mathrm{mm}^{2}$ 程度しかなく, $N=0.3_{c} N_{u}+$ $0.5 N_{u}$ の圧縮軸力を受けている柱を想定して柱軸力を設定した。た だし， F 9 9 試験体 C09FC1515 と C09BC1515 は，比較として $N=0.15_{c} N_{u}+0.5_{s} N_{u}$ の圧縮軸力を受ける柱として計画した。

\section{2 梁試験体}

梁試験体の試験体計画を Table5, 試験体形状の一例を Fig.3 にそ れぞれ示す。いずれの試験体とも曲げ破壊に対してせん断破壊が先 行することを想定した SRC 梁として計画し, コンクリート強度, 梁幅 $b$ に対する鉄骨フランジ位置でのコンクリート有効幅 $b$ ' ( 梁幅 $^{-}$ 一鉄骨フランジ幅) の比 $b^{\prime} / b$ およびせん断補強筋比 $p_{W}$ を変数とした 合計 6 体の非充腹型 (格子形) SRC 梁を製作した。

全試験体の梁断面は $200 \mathrm{~mm} \times 400 \mathrm{~mm}$, 内法長さは $1600 \mathrm{~mm}$ と した。 $F_{c}$ は $18 \mathrm{~N} / \mathrm{mm}^{2}$ と $9 \mathrm{~N} / \mathrm{mm}^{2}$ の 2 種類とした。調合表を Table6 に示す。
Table 6 Mix proportion of concrete

\begin{tabular}{c|c|c|c|c|c|c|c}
\hline$F_{c}$ & $\begin{array}{c}\text { Water } \\
\left(\mathrm{kg} / \mathrm{m}^{3}\right)\end{array}$ & $\begin{array}{c}\text { Cement } \\
\left(\mathrm{kg} / \mathrm{m}^{3}\right)\end{array}$ & $\begin{array}{c}\text { Fine } \\
\text { aggregate } \\
\left(\mathrm{kg} / \mathrm{m}^{3}\right)\end{array}$ & $\begin{array}{c}\text { Coarse } \\
\text { aggregate } \\
\left(\mathrm{kg} / \mathrm{m}^{3}\right)\end{array}$ & $\begin{array}{c}\text { Admixture } \\
\left(\mathrm{kg} / \mathrm{m}^{3}\right)\end{array}$ & $\begin{array}{c}\text { Water- } \\
\text { cement } \\
\text { ratio } \\
(\%)\end{array}$ & $\begin{array}{c}\text { Fine } \\
\text { aggregate } \\
\text { ratio } \\
(\%)\end{array}$ \\
\hline 18 & 205 & 234 & 1079 & 719 & 1.76 & 87.5 & 60.8 \\
9 & 205 & 186 & 1119 & 716 & 1.67 & 110 & 61.6 \\
\hline
\end{tabular}

Table 7 Mechanical properties of concrete

\begin{tabular}{|c|c|c|c|c|}
\hline Specimen & $\begin{array}{c}F_{c} \\
\left(\mathrm{~N} / \mathrm{mm}^{2}\right)\end{array}$ & $\begin{array}{c}\sigma_{B} \\
\left(\mathrm{~N} / \mathrm{mm}^{2}\right)\end{array}$ & $\begin{array}{c}\sigma_{t} \\
\left(\mathrm{~N} / \mathrm{mm}^{2}\right)\end{array}$ & $\begin{array}{c}E \\
\left(\mathrm{~N} / \mathrm{mm}^{2}\right) \\
\end{array}$ \\
\hline B182032 & \multirow{3}{*}{18} & \multirow{3}{*}{16.1} & \multirow{3}{*}{1.72} & \multirow{3}{*}{21703} \\
\hline B183232 & & & & \\
\hline B183257 & & & & \\
\hline B092032 & \multirow{3}{*}{9} & 9.4 & 1.32 & 16367 \\
\hline B093232 & & 9.2 & 1.25 & 16000 \\
\hline B093257 & & 8.6 & 1.11 & 16734 \\
\hline
\end{tabular}

Table 8 Mechanical properties of steel

\begin{tabular}{l|c|c|c}
\hline \multicolumn{1}{c|}{ Steel } & $\begin{array}{c}\sigma_{y} \\
\left(\mathrm{~N} / \mathrm{mm}^{2}\right)\end{array}$ & $\begin{array}{c}\sigma u \\
\left(\mathrm{~N} / \mathrm{mm}^{2}\right)\end{array}$ & $\begin{array}{c}\text { Elongation } \\
(\%)\end{array}$ \\
\hline Angle & 309 & 435 & 26.8 \\
\hline Tie plate & 269 & 360 & 30.3 \\
\hline Main rebar & 321 & 454 & 30.2 \\
\hline Stirrup & 356 & 495 & 13.4 \\
\hline
\end{tabular}

鉄骨について,$b^{\prime} / b=0.32$ の試験体は $\mathrm{L}-65 \times 65 \times 6$ の山形鋼， $b^{\prime} / b$ $=0.57$ の試験体は L- $65 \times 40 \times 6$ の山形鋼 $(\mathrm{L}-65 \times 65 \times 6$ のフランジを切 断）と PL6-30 の帯板を用いて格子形に組み立てた。主筋は 6- $\phi 16$, せん断補強筋はD6 を用いた。柱試験体と同様に, 山形鋼と帯板の 接合は 2-M6(孔径 $\phi 7$ ) の六角穴付きボルトを用いた。

試験体に用いたコンクリートおよび鋼材の材料試験結果一覧を Table7, Table8 にそれぞれ示す。

\section{3 載荷方法}

載荷は Fig.4 に示す載荷装置を使用し, 所定の圧縮軸力 $N$ を導入 後, 正負繰返しの逆対称モーメントを漸増載荷した。加力サイクル は部材角 $R$ (スタブ間の相対水平変位を試験体内のりで除した值） を変位制御し, 柱試験体は $R= \pm 0.25 \% \mathrm{rad}$.を 1 サイクル行なった後, 
次に $R= \pm 0.5 \% \mathrm{rad}$.を 2 サイクル行い, それ以後は直前の振幅に対し て $R$ を $\pm 0.5 \% \mathrm{rad}$. 漸増させる正負繰り返し載荷を 2 サイクルずつ行 って, 顕著な耐力低下を生じるか, 最大 $\pm 5.0 \% \mathrm{rad}$.の振幅で実験を 終了した。梁試験体も柱試験体と同様の加力サイクルであるが， $R=$

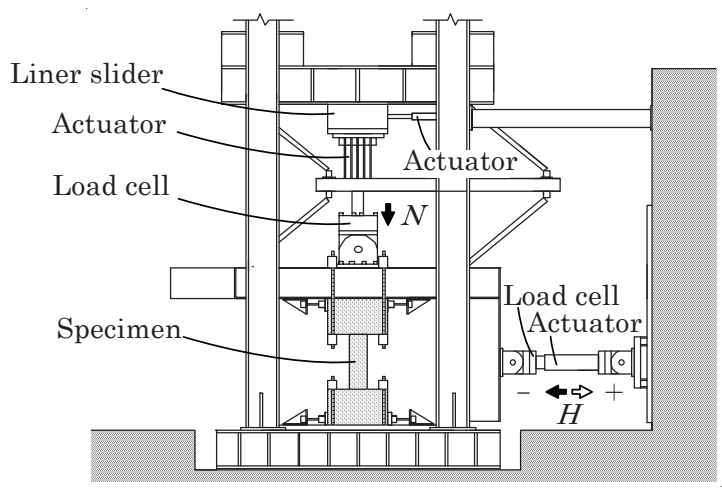

Fig.4 Loading apparatus

•: Tensile yield of flange (strong-axis bending)

$\circ$ : Compressive yield of flange (strong-axis bending)

$\square$ : Compressive yield of flange (weak-axis bending)

$\diamond:$ Compressive yield of main rebar

$\Delta$ : Tensile yield of hoop

$\nabla:$ Max strength
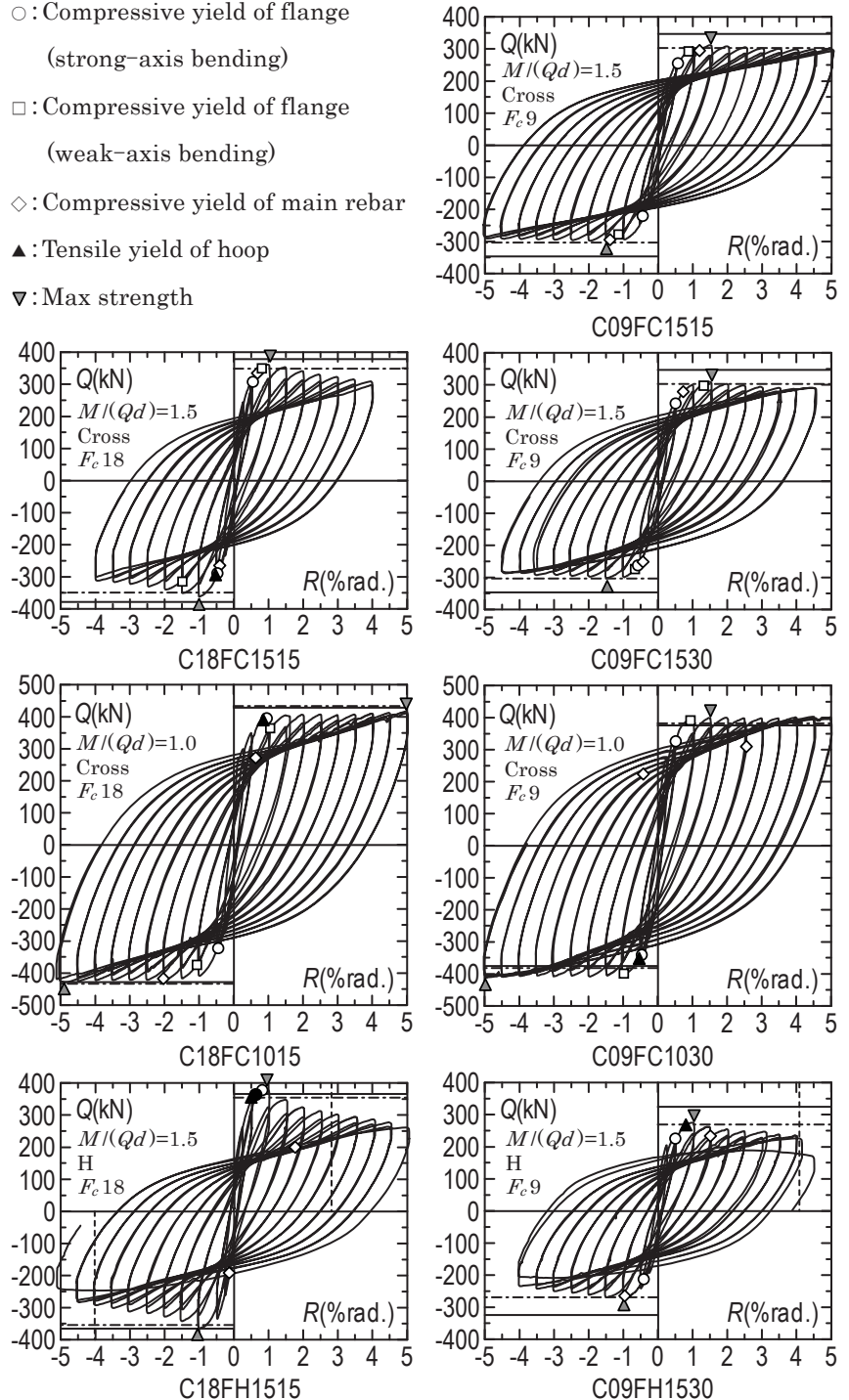
C09FC1030

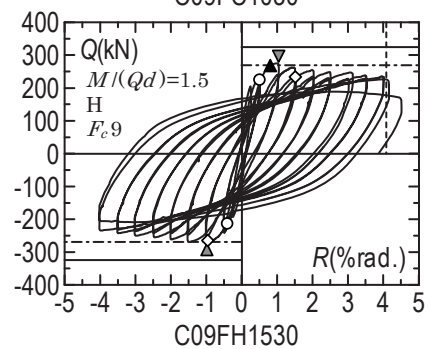

(a) Full web type $\pm 2.0 \% \mathrm{rad}$.以降は直前の振幅に対して $R$ を $1.0 \% \mathrm{rad}$.漸増させた。

ひずみ度は強軸および弱軸 $\mathrm{H}$ 形鋼のフランジとウェブ, 強軸およ び弱軸の山形鋼と帯板，主筋，せん断補強筋のそれぞれにひずみゲ ージを貼付けて計測した。

\section{3. 履歴特性と破壊状況}

\section{1 柱試験体}

全試験体の履歴曲線を Fig. 5 に示寸。せん断力 $Q$ は水平力の計測 值 $H$ に対して軸力 $N$ の作用による $P \Delta$ 効果を考慮した值である。図 中の実線 (直線) は SRC 耐震診断基準4)に示されるせん断終局強度の 計算值 $Q_{s u}$, 一点鎖線は後述する 5 章で提案するせん断終局強度の計

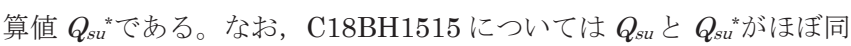
值となる。点線は最大強度に到達以後せん断力が $20 \%$ 低下した時の 部材角 (以後, 限界変形角之称す)である。また, 最大強度時のひび割 れ発生状況の一例を Fig. 6 に示す。以下，充腹型 SRC 柱と非充腹型 $\mathrm{SRC}$ 柱のそれぞれについて，破壊状況と履歴特性について述べる。

- : Tensile yield of angle (strong-axis bending)

$\circ$ : Compressive yield of angle (strong-axis bending)

$\square$ : Compressive yield of angle (weak-axis bending)

$\diamond:$ Compressive yield of main rebar

$\Delta$ : Tensile yield of hoop

$\nabla:$ Max strength
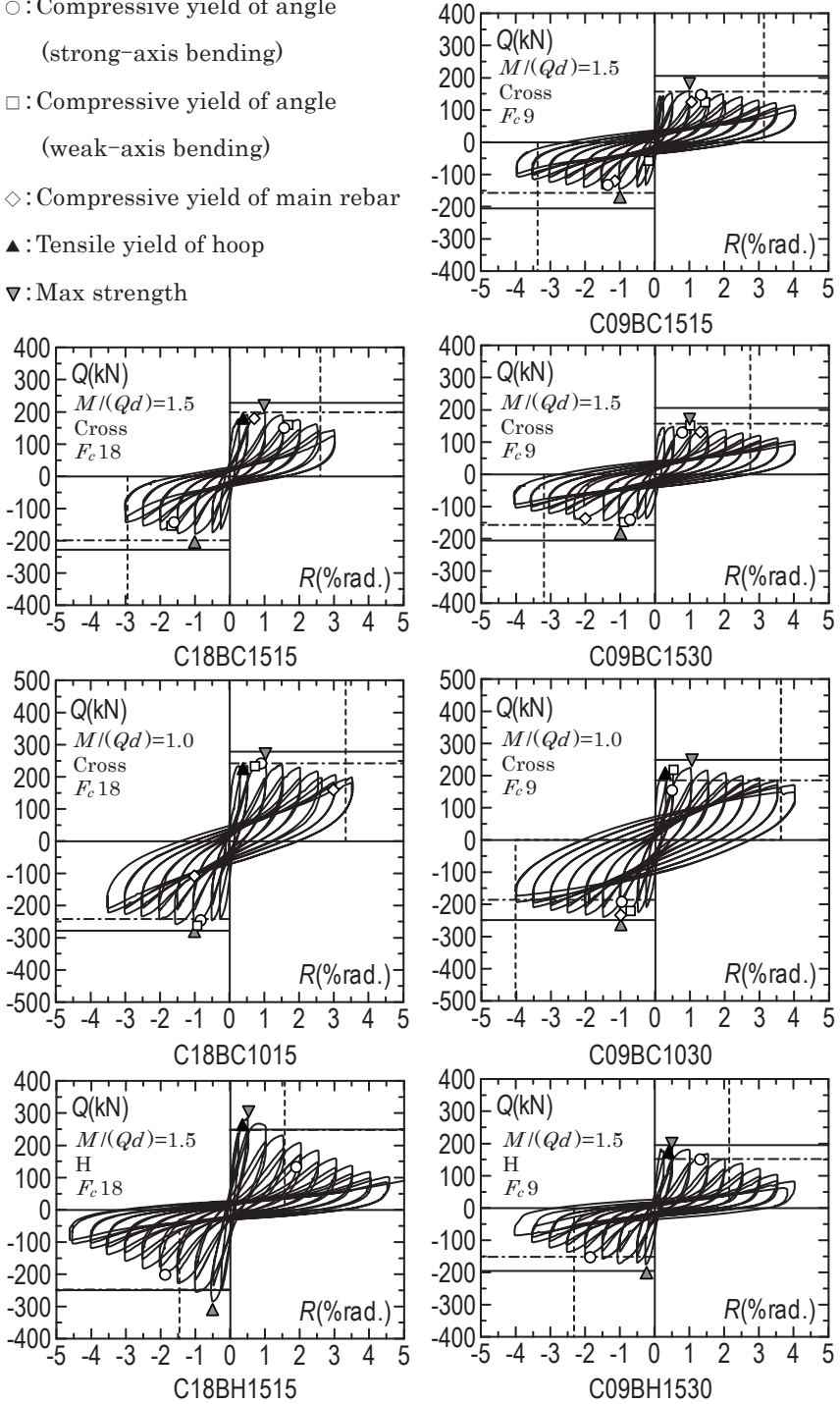
C09BC 1030

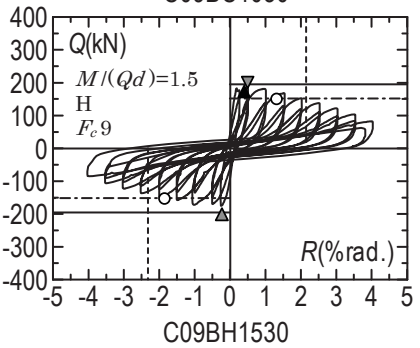

(b) Open web type

Fig.5 Hysteresis loops of columns 


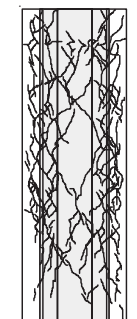

C09FC1530

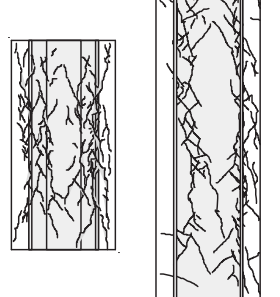

(a) Full web type

$\mathrm{C} 09 \mathrm{FH} 1530$
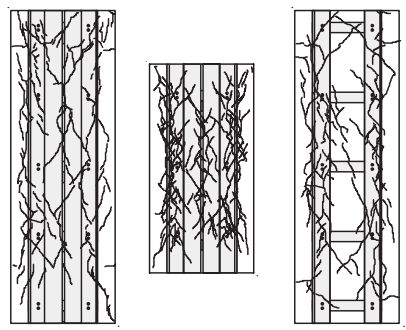

Fig.6 Crack patterns of failure stage for test columns

$\triangle: R=0.25 \% \mathrm{rad}$., $\circ: R=0.5 \% \mathrm{rad}$., $\times: R=1.0 \% \mathrm{rad}$., 安: $R=3.0 \% \mathrm{rad}$.

$\bullet:$ Position of strain gage for main rebar

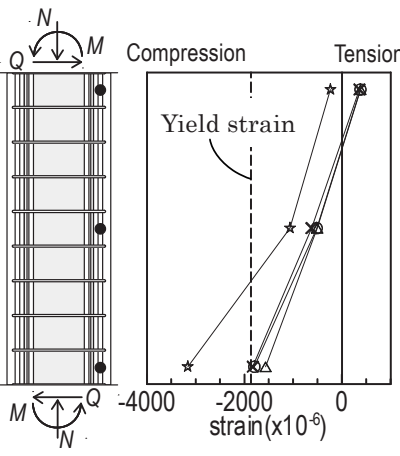

C09FH1530 (with deformed bar)

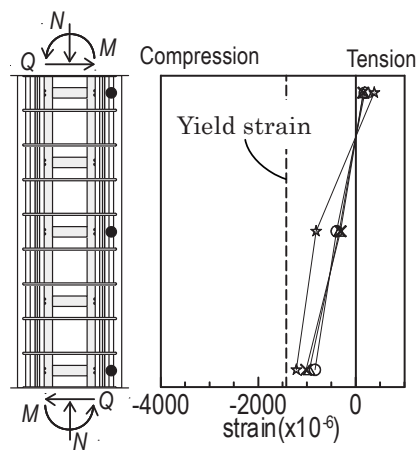

C09BH1530 (with round bar)
Fig.7 Strain distributions of main rebar

\section{(a) 充腹型}

十字形鉄骨が内蔵された充腹型 SRC 柱の破壊進展状況は, $R= \pm 0.25 \% \mathrm{rad}$.の振幅で部材中央近傍に斜めひび割れが発生し, $R= \pm 0.5 \% \mathrm{rad}$.の振幅では斜めひび割れが材端へと進展し, $R= \pm 1.0 \% \mathrm{rad}$.の振幅で強軸フランジに沿った位置でせん断付着ひび 割れが発生して, $R= \pm 1.0 \sim 1.5 \% \mathrm{rad}$.の振幅で耐力の上昇がほぼ頭打 ちとなった。それ以後の振幅では, 斜めひび割れとせん断付着ひび 割れが拡幅してコンクリートの損傷が進み, 最終的には強軸フラン ジに沿った位置でせん断付着破壞が卓越する破壊形式となったが, いずれの試験体とも限界変形角に達することなく，履歴ループの形 状は実験終了まで紡錘形を保っている。

$\mathrm{H}$ 形鉄骨が内蔵された充腹型 $\mathrm{SRC}$ 柱の破壊進展状況は, $R= \pm 0.25$ 〜 $0.5 \% \mathrm{rad}$.の振幅で部材端部の斜めひび割れおよびフランジに沿 った位置でせん断付着ひび割れが発生し， $R= \pm 1.0 \% \mathrm{rad}$.の振幅で部 材中央近傍に斜めひび割れを生じて最大強度に達した。それ以後の 振幅では，斜めひび割れおよびせん断付着ひび割れが拡幅してコン クリートの損傷が進み, 最終的にはフランジに沿った位置でせん断 付着破壊が卓越する破壊形式となり，かぶりコンクリートの剥離を 伴いながら耐力低下が進んで限界変形角に達した。履歴ループの形 状は実験終了までほぼ紡錘形を保っているが，十字形鉄骨が内蔵さ れた柱と比べると最大強度以降の耐力低下が大きくなった。

内蔵鉄骨の形状に関わらず，最大強度に達した時に強軸フランジ は圧縮降伏している。せん断補強筋は未降伏の試験体もあったが, 降伏ひずみ度に近い值に達していた。また，コンクリート強度が小 さい柱は最大強度が小さくなったが, 限界変形角は大きくなる傾向
が見られた。八十島らの研究 6)によると, 低強度コンクリートの $\mathrm{RC}$ 柱は軸力比が大きくなる影響を受けて，材端部のコンクリートが圧 壊するせん断圧縮破壊を生じやすくなることが特徴として挙げられ ており, 最大強度に到達後の履歴ループは逆 $\mathrm{S}$ 字形のスリップ性状 を示し，急激に耐力低下した後に軸力を保持できなくなる場合があ ると報告されている。一方，SRC 柱では，内蔵鉄骨の形状に関わら ず最終的には強軸フランジに沿った位置でせん断付着破壊が卓越す る破壞形式となっていることが特徵として挙げられるが, 低強度コ ンクリートであっても，せん断圧縮破壊する $\mathrm{RC}$ 柱ほど脆性的な挙 動を示すことはなく，実験終了まで紡錘形の履歴ループを保ち，軸 力を保持している。 $\mathrm{SRC}$ 柱はコンクリートの破壊の進展と共にコン クリートが負担している圧縮力が小さくなっても，コンクリートが 負担していた圧縮力を鉄骨が代わりに負担することで優れた変形能 力を有することが実験的・理論的に明らかにされている7)。

(b) 非充腹型

非充腹型 $\mathrm{SRC}$ 柱の破壊進展状況は, 充腹型 $\mathrm{SRC}$ 柱と比べて $R$ が 大きくなってから山形鋼が圧縮降伏している点が異なるが，コンク リートのひび割れ発生状況は充腹型 SRC 柱とほぼ同様であり, 最 終的には強軸山形鋼のフランジに沿った位置でせん断付着破壊が卓 越する破壊形式となった。

履歴特性については, 充腹型 $\mathrm{SRC}$ 柱と同様にコンクリート強度 が小さい柱は最大強度が小さくなったが限界変形角は大きくなった。 また, 充腹型 SRC 柱と比べると最大強度に達寸る時の $R$ が小さく なる傾向があり, 最大強度以降の耐力低下が大きく, 限界変形角は 小さくなった。特に, $\mathrm{H}$ 形鉄骨が内蔵された柱は $R= \pm 0.25 \sim 0.5 \% \mathrm{rad}$. の小さな振幅で最大強度に達し， $R= \pm 1.0 \% \mathrm{rad}$.程度以降は大きく耐 力低下した。履歴ループはせん断圧縮破壊する $\mathrm{RC}$ 柱 ${ }^{6), 8}$ ) と同様のス リップ性状を示しエネルギー吸収能力に乏しい形状となったが，実 験終了まで軸力を保持している。

なお，充腹型 SRC 柱は主筋に異形棒鋼を用い，非充腹型 SRC 柱 は主筋に丸鋼を用いている。十字形鉄骨と比較して鉄骨量が少なく $\mathrm{RC}$ 部分の性状が現れやすい $\mathrm{H}$ 形鉄骨内蔵の柱 $\mathrm{C} 09 \mathrm{FH} 1530$ と C09BH1530 について Fig.7 に示寸主筋のひずみ度分布を見ると， ほぼ同様のひずみ勾配を有して圧縮側へシフトしており,なおかつ, コンクリートのひび割れ進展状況も同様であった。本実験では主筋 の付着力の違いが履歴特性に与える影響は大きくなかったものと思 われる。また，後述の Table9 によって鉄骨の形式と主筋の種類以 外の変数が同一の試験体を比較すると, 最大強度の実験值 $Q_{\exp }$ の差 と鉄骨部分の強度の計算值 ${ }_{s} Q_{u}$ の差は近い值となる試験体が多い。 さらに，本実験と主筋比およびせん断補強筋比がほぼ等しいせん断 破壊を生じる低強度コンクリートの $\mathrm{RC}$ 柱の実験 8 によると, 異形 棒鋼と丸鋼のいずれの主筋を用いた場合においても履歴ループはス リップ性状を示している。したがって, 充腹型 SRC 柱と非充腹型 $\mathrm{SRC}$ 柱の履歴特性の差異は内蔵された鉄骨の違いの影響を大きく 受けているものと考えられる。

（c）鉄骨の形式と形状が柱の性能に及ぼす影響

普通強度コンクリートの $\mathrm{SRC}$ 柱では非充腹型と比べて充腹型 $\mathrm{SRC}$ 柱の変形能力が高くなることは知られているが 3)，低強度コン クリートの SRC 柱についても同様であった。さらに, 普通強度コ ンクリートの $\mathrm{SRC}$ 柱と比較して, 低強度コンクリートの $\mathrm{SRC}$ 柱は 
限界変形角が大きくなった。これは, Fig.2 に示されるように低強 度コンクリートは軟化域における強度低下がゆるやかであることに 加えて, コンクリートが低強度になるほど部材の耐力に対して鉄骨 部分が負担する耐力の割合が大きくなることが影響していると考え られる。また, 十字形鉄骨と比較して H 形鉄骨が内蔵された柱の限 界変形角が小さくなるのは, フランジに取り囲まれるコンクリート が受ける拘束効果が異なることが影響していると思われ, 圧縮力を 受ける十字形鉄骨内側のコンクリートは, 横拘束を受けて軟化域に おける強度低下が抑えられることが明らかにされている9)。

本実験では, 鉄骨の形式と形状に関わらず実験終了まで軸力保持 能力は失われていない。SRC 規準・第 6 版 10)では(1) 式を満足すれ ば, $R= \pm 1.0 \% \mathrm{rad}$.程度の変形能力を確保できることが示されており, 本実験における柱の軸力はいずれも(1) 式を満足しており, 低強度 コンクリートの SRC 柱に対しても適用できることがわかった。

$$
N \leqq \frac{1}{3}{ }_{c} N_{u}+\frac{2}{3}{ }_{s} N_{u}
$$

\section{2 梁試験体}

梁試験体の履歴曲線を Fig.8, 最大強度時のひび割れ発生状況を Fig.9 にそれぞれ示す。

$b^{\prime} / b=0.32$ の格子形 $\mathrm{SRC}$ 梁の破壊進展状況は, $R= \pm 0.5 \% \mathrm{rad}$.まで の振幅で部材端部に斜めひび割れおよびフランジに沿った位置にせ ん断付着ひび割れが発生し， $R= \pm 1.0 \% \mathrm{rad}$.の振幅で最大強度に達し た。それ以後の振幅では, 斜めひび割れおよびせん断付着ひび割れ が拡幅してコンクリートの損傷が進み, コンクリートの剥離を伴い ながら急激に耐力低下が進み限界変形角に達した。

$b^{\prime} / b=0.57$ の格子形 $\mathrm{SRC}$ 梁の破壊進展状況は, $R= \pm 0.5 \% \mathrm{rad}$.の振 幅で部材端部に斜めひび割れが発生し， $F_{c} 18$ の梁は $R= \pm 1.5 \% \mathrm{rad}$. で, $F_{c} 9$ の梁は $R= \pm 1.0 \% \mathrm{rad}$.でそれぞれ最大強度に達した。それ以

- : Tensile yield of angle, $\boldsymbol{\Delta}$ : Tensile yield of stirrup, $\nabla$ : Max strength
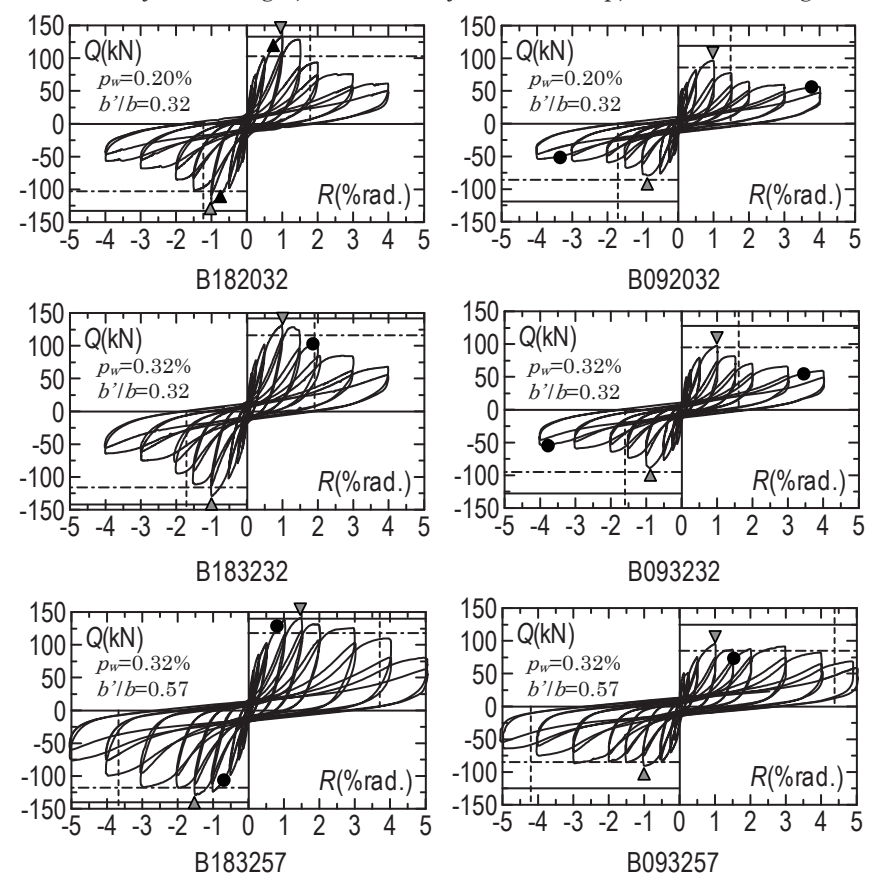

(a) Fc18

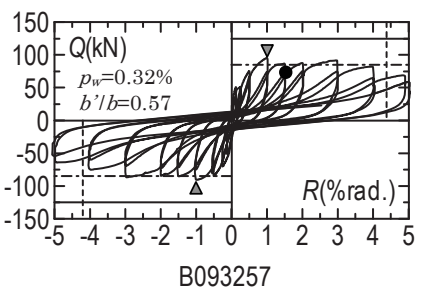

(b) Fc9

Fig. 8 Hysteresis loops of beams
後の振幅では斜めひび割れが拡幅するが急激な耐力低下はなく, $F_{c} 18$ の梁は $R= \pm 2.0 \% \mathrm{rad}$.で, $F_{c} 9$ の梁は $R= \pm 1.5 \% \mathrm{rad}$.でそれぞれ主 筋に沿った位置でせん断付着ひび割れが発生し，コンクリートの損 傷, 剥離を伴いながら徐々に耐力低下が進み限界変形角に達した。

最大強度に達した時の鋼材のひずみ度を確認すると, B182032 は せん断補強筋が引張降伏, B183257 は山形鋼のフランジが引張降伏 しているが，その他の鋼材は未降伏であり，全試験体ともに履歴ル 一プはせん断引張破壊や付着割裂破壊する $\mathrm{RC}$ 梁 ${ }^{6), 8)}$ と同様のスリ ップ性状を示しており, エネルギー吸収能力に乏しい形状となった。 実験変数の影響を確認すると, コンクリート強度が小さい梁は最 大強度も小さくなっていることがわかる。 $p_{W}$ の違いによる影響は顕 著ではない。 $b^{\prime} / b$ が異なる梁を比較すると, 最大強度は大きく変わ

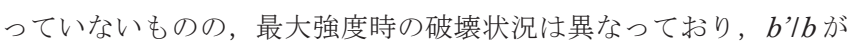
小さい試験体は早期にせん断付着ひび割れを生じて, 限界変形角が 小さくなっている。ただし，いずれの試験体ともに最終的にはせん 断付着破壊が卓越する破壊形式となった。

\section{SRC 耐震診断基準式の検証}

$\mathrm{SRC}$ 耐震診断基準では，コンクリートの圧縮強度が $13.5 \mathrm{~N} / \mathrm{mm}^{2}$ 以上であることを適用範囲とし, 充腹型 SRC 柱のせん断終局強度 は修正荒川 min 式に基づく $\mathrm{RC}$ 部分の強度に鉄骨部分の強度 ${ }_{s} Q_{u}$ を 加えた (2) 式が示されている。なお, 梁に関しては軸方向応力度 $\sigma_{0}=0$ として評価される。

$$
\begin{aligned}
Q_{s u}=\left\{k_{c s} \frac{0.053 r p_{t}{ }^{0.23}\left(18+\sigma_{B}\right)}{M(Q \cdot d)+0.12}\right. & \\
& \left.+0.85 \sqrt{p_{W} \cdot \sigma_{W y}}+0.1 \sigma_{0}\right\} b \cdot{ }_{r} j+{ }_{s} Q_{u}
\end{aligned}
$$

ここで, ${ }_{r} p_{t}$ は引張鉄筋比, ${ }_{r} j$ は $\mathrm{RC}$ 部分の応力中心間距離, ${ }_{s} Q_{u}$ は 鉄骨部分の強度で負担軸力を 0 とした時の曲げ終局強度 ${ }_{s} Q_{m u}$ とせ 儿断終局強度 ${ }_{s} Q_{s u}$ の小さい方の值, その他の記号は文献 4 を参照さ れたい。なお， $k_{c s}$ はせん断付着破壞の影響を考慮したコンクリート の負担強度に対する低減係数であり(3)式が示されている。

$$
\left.k_{c s}=\frac{b^{\prime}}{b}+0.5 \quad \text { (ただし, } k_{c s} \leqq 1.0\right)
$$

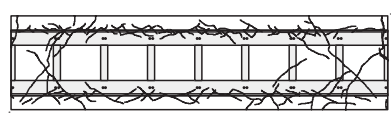

B182032

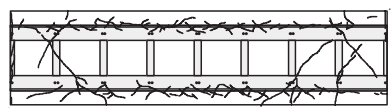

B183232

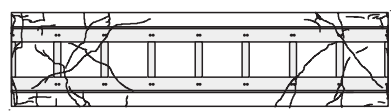

B183257

(a) Fc18

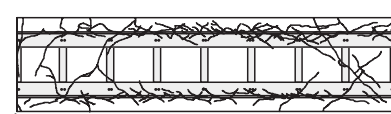

B092032

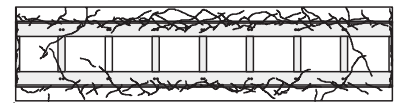

B093232

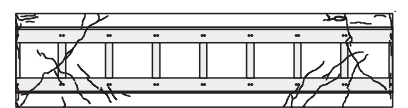

B093257

(b) Fc9
Fig. 9 Crack patterns of failure stage for test beams 


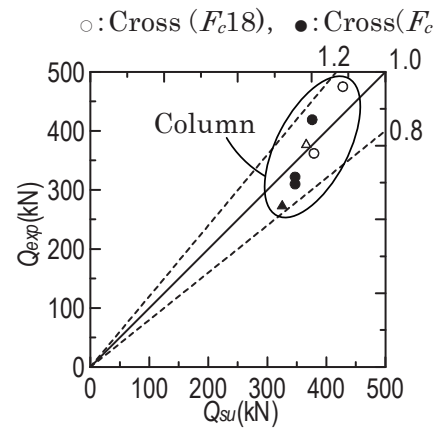

(a) Full web type

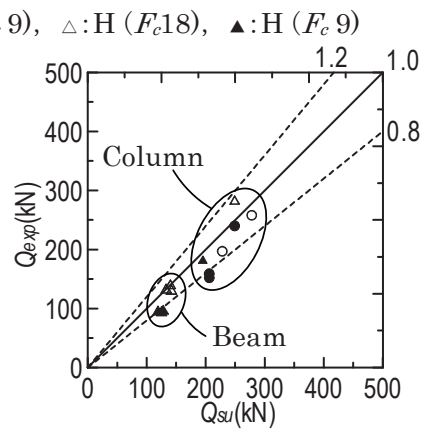

(b) Open web type
Fig.10 Comparisons between observed and calculated values

格子形鉄骨の非充腹型 SRC 柱のせん断終局強度は, 修正荒川 min 式に基づく強度におけるせん断補強筋の負担強度に格子材の負担強 度を加えた(4)式が示されている。

$$
\begin{aligned}
Q_{s u}=\left\{\frac{0.053 p_{t}^{0.23}\left(18+\sigma_{B}\right)}{M(Q \cdot d)+0.12}\right. & \\
& \left.+0.85 \sqrt{p_{W^{\bullet}} \sigma_{W y}+\frac{s p_{W^{\bullet}} s \sigma_{W y}}{2}}+0.1 \sigma_{0}\right\} b \cdot j
\end{aligned}
$$

ここで, $p_{t}$ は主筋と鉄骨弦材を考慮した引張鋼材比, ${ }_{s} p_{w}$ と ${ }_{s} \sigma_{w y}$ は 帯板比と帯板の降伏強度, $j$ は応力中心間距離である。

(2),(4) 式による計算値 $Q_{s u}$ と最大強度の実験值 $Q_{\exp }$ の比較を Fig.10に示す。充腹型 $\mathrm{SRC}$ 部材について, $Q_{\text {exp }} / Q_{s u}$ の平均值は 0.98 , 変動係数は $10.7 \%$, 不合格率 $\left(Q_{e x p}<Q_{s u}\right.$ となる試験体数を全試験体数 で除した值） $57.1 \%$ であた。非充腹型 SRC 部材について, $Q_{\text {exp }} / Q_{s u}$ の平均值は 0.89 , 変動係数は $13.6 \%$, 不合格率は $76.9 \%$ であった。 鉄骨の形式に関わらず，コンクリート圧縮強度が適用範囲を下回る 試験体に限ると, $Q_{e x p} / Q_{s u}$ の平均值は 0.87 , 変動係数は $13.2 \%$, 不 合格率は $90.9 \%$ であった。全試験体を通して実験值が計算值を下回 る場合が多くあり, 特に, 適用範囲を下回る試験体に限ると 1 体を 除き他の全ての試験体は危険側に評価されることが明らかとなった。

\section{5. 低強度コンクリートに対応できる評価式}

\section{1 せん断終局強度式の提案}

$\mathrm{SRC}$ 耐震診断基準に示されるせん断終局強度式 (以後, 耐震診断 基準式と称す）では，実験值が計算值を下回る試験体が多くあるた め, 低強度コンクリートへ対応することも可能な SRC 部材のせん 断終局強度式の提案を行なう。

耐震診断基準式は，充腹型および非充腹型でラチス形鉄骨の場合 は (2) 式, 非充腹型で格子形鉄骨の場合は (4) 式と異なる構成の評価 式が示されている。しかしながら，本実験の SRC 柱の破壊状沉を 見ると, 鉄骨の形式によって最大強度時の破壊性状に差異はなく, また, 最大強度時に鉄骨とコンクリートは一体となって挙動しない ことを考慮して, 鉄骨の形式に関わらず, $\mathrm{SRC}$ 部材のせん断終局強 度を $\mathrm{RC}$ 部分の強度 ${ }_{r c} Q_{u}$ に鉄骨部分の強度 ${ }_{s} Q_{u}$ を加えた (5) 式によっ て評価する。

$$
Q_{s u}{ }^{*}={ }_{r c} Q_{u}+{ }_{s} Q_{u}
$$

${ }_{r c} Q_{u}$ は $\mathrm{RC}$ 部材と同様のせん断圧縮破壊やせん断引張破壊等によ
って決まる強度 ${ }_{r c} Q_{s u 1}$ と $\mathrm{SRC}$ 部材特有のせん断付着破壊によって決 まる強度 ${ }_{r c} Q_{s u 2}$ が考えられる。

${ }_{r c} Q_{s u 1}$ に関しては, 低強度コンクリートに対応できる $\mathrm{RC}$ 部材のせ ん断終局強度式として, 修正荒川 min 式に基づく強度におけるせん 断補強筋負担強度をコンクリート強度に応じて低減させる (6) 式が 提案されており 6)，これを $\mathrm{SRC}$ 部材における $\mathrm{RC}$ 部分に適用する。

$$
{ }_{r c} Q_{s u 1}=\left\{\frac{0.053 r p_{t}^{0.23}\left(18+\sigma_{B}\right)}{M(Q \cdot d)+0.12}\right.
$$

$$
\left.+\alpha_{L} \sqrt{p_{W} \cdot \sigma_{W y}}+0.1 \sigma_{0}\right\} b^{\cdot}{ }_{r j}
$$

$$
\alpha_{L}=0.038 \sigma_{B} \quad \text { （ただし， } \alpha_{L} \leqq 0.85 ）
$$

${ }_{r c} Q_{s u 2}$ に関しては, (2) 式と同様に修正荒川 $\min$ 式に基づく強度に おけるコンクリート負担強度を低減する (8) 式を用いるが, 低強度 コンクリートに対応できる $k_{c s}$ にいて次節で考察する。

$$
\begin{aligned}
& { }_{r c} Q_{s u 2}=\left\{k_{c s} \frac{0.053 r p_{t}{ }^{0.23}\left(18+\sigma_{B}\right)}{M(Q \cdot d)+0.12}\right. \\
& \left.+0.85 \sqrt{p_{w} \cdot \sigma_{w y}}+0.1 \sigma_{0}\right\} b_{r} j
\end{aligned}
$$

鉄骨部分の強度に関して, SRC 耐震診断基準では安全側へ配慮し て弱軸鉄骨の強度を考慮していないが，本論では ${ }_{r c} Q_{u}$ の検証を精度 よく行うために， ${ }_{s} Q_{u}$ に関しては本実験の実強度に近い值を得るこ とを意図して, 以下に示される方法を用いて曲げ終局強度 ${ }_{s} Q_{m u}$ とせ 几断終局強度 ${ }_{s} Q_{s u}$ の小さい方の值とする。

$$
{ }_{s} Q_{u}=\min \left({ }_{s} Q_{m u},{ }_{s} Q_{s u}\right)
$$

${ }_{s} Q_{m u}$ は充腹型, 非充腹型ともに軸力と終局曲げモーメントの相関 関係を求め, 終局曲げモーメントをせん断スパンで除して得られる 值とする。

${ }_{s} Q_{s u}$ について, 充腹型十字形鉄骨の場合は強軸ウェブのせん断強 度に直交フランジの曲げで決まる強度とせん断で決まる強度の小さ い方の值を加えた值とする。強軸ウェブは直交ウェブとコンクリー トによって補剛されるため塑性変形能力が高く, 強軸ウェブがせん 断で決まる場合でも直交フランジの強度を加えた值に達すると考え ている。充腹型 $\mathrm{H}$ 形鉄骨の場合は強軸ウェブのせん断強度とする。 格子形鉄骨の場合は強軸の鉄骨弦材両端と帯板両端に塑性ヒンジを 生じて崩壊機構が形成されるときの強度とする 11 。。なお，(5)式を用 いて ${ }_{r c} Q_{u}$ と ${ }_{s} Q_{u}$ を算定するにあたり， $\mathrm{RC}$ 部分と鉄骨部分の負担軸 力は, SRC 規準に示される一般化累加強度式によって終局曲げ強度 を算定する際にそれぞれに振り分けられる軸力の值とし，充腹型鉄 骨で $M I(Q \cdot d)=1.5$ の場合は ${ }_{s} Q_{m u}<{ }_{s} Q_{s u}$, 充腹型鉄骨で $M I(Q \cdot d)=1.0$ の 場合は ${ }_{s} Q_{m u}>_{s} Q_{s u}$, 格子形鉄骨の場合はいずれも ${ }_{s} Q_{m u}>_{s} Q_{s u}$ となった。 5.2 低減係数 $k_{c s}$

$\mathrm{SRC}$ 部材のせん断付着破壊は, 柱幅に対する鉄骨幅の比が大きく なると起こりやすいことが明らかにされており 12$)$ ，本研究における 梁の実験でも同様であった。充腹型 SRC 部材と非充腹型 SRC 部材 のそれぞれについて，(5)，(8)および(9)式を用いた計算值 $Q_{s u}{ }^{*}$ と最 大強度の実験值 $Q_{\text {exp }}$ が一致する值として同定した $k_{c s}$ を Fig.11に示 
す。Fig.11(a),(b)の実線は $F_{c} 18, F_{c} 9$ それぞれの試験体をグルーピ ングして求めた $b^{\prime} / b-k_{c s}$ 関係の近似線である。 $\mathrm{SRC}$ 耐震診断基準で は $k_{c s}$ を(3) 式のように $b^{\prime} / b$ の関数として表しており,$b^{\prime} / b-k_{c s}$ 関係を 示すと Fig.11(a),(b)の実線となる。

鉄骨の形式と鉄筋の種類に関わらず, $b^{\prime} / b-k_{c s}$ 関係の近似線は, (1)コンクリート強度が小さいと $k_{c s}$ も小さい, (2) $F_{c} 18$ では $b^{\prime} / b$ が小 さいと $k_{c s}$ も小さい, (3) $F_{c} 18$ と比較して $F_{c} 9$ の $k_{c s}$ は $b^{\prime} / b$ の影響が 小さい(近似線の傾きが小さい), 等の特徴が見られる。 $F_{c} 18$ の近似 線のように $b^{\prime} / b$ が小さくなると $k_{c s}$ も小さくなっているのは, 柱幅 に対するコンクリートの有効幅が小さくなると, コンクリートが鉄 骨で分断されやすくなり, 部材のせい方向に分割されたコンクリー トストラットの抵抗力が, 分割されずに一体となってストラットが 形成される場合の抵抗力より小さくなることが影響していると思わ れる。分割されないコンクリートストラットの強度に対する分割さ れたコンクリートストラットの強度の比の下限は 0.5 程度となるこ とが理論的に明らかにされており ${ }^{12)}$, 本実験の $k_{c s}$ の同定值の近似 線を外挿した值も概敉 0.5 を指向している。しかしながら, Fig.11

: $\operatorname{Column}\left(F_{c} 18\right), \quad \bullet: \operatorname{Column}\left(F_{c} 9\right), \quad \Delta: \operatorname{Beam}\left(F_{c} 18\right), \quad \mathbf{\Delta}: \operatorname{Beam}\left(F_{c} 9\right)$

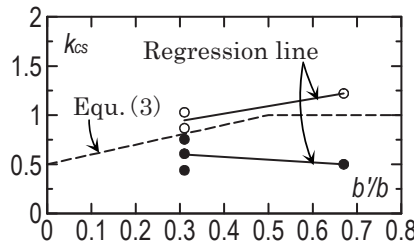

(a) Full web type

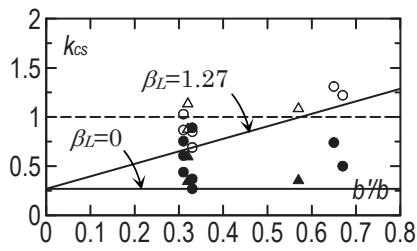

(c) Proposal line

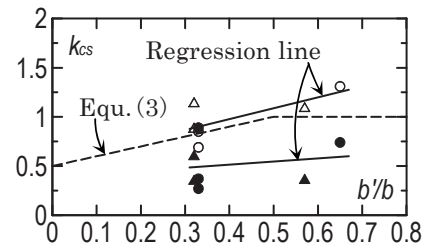

(b) Open web type

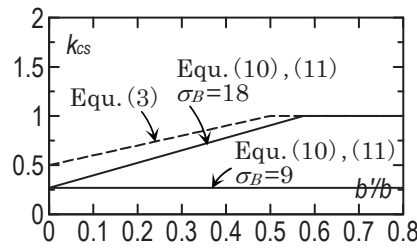

(d) Proposal and Existing
Fig. 11 Interaction of $b^{\prime} / b$ and $k_{c s}$ (a),(b)に示されるように低強度コンクリートの SRC 部材に対する $k_{c s}$ の同定值は 0.5 を下回っている試験体があり, 本論ではせん断終 局強度を安全側に評価することを目的として，鉄骨の形式と鉄筋の 種類に関わらず，下值值を 0.27 ，上限值を 1.0 として， $k_{c s}$ を(3) 式 と同様に $b^{\prime} / b$ の関数として表し, さらに, コンクリート強度による 低減係数 $\beta_{L}$ を $b^{\prime} / b$ に乗じる $(10)$ 式を提案する。

$$
\left.k_{c s}=\beta_{L} \cdot \frac{b^{\prime}}{b}+0.27 \quad \text { (ただし, } 0.27 \leqq k_{c s} \leqq 1.0\right)
$$

コンクリート圧縮強度 $\sigma_{B}$ の適用範囲を $9 \mathrm{~N} / \mathrm{mm}^{2}$ 以上とし, $F_{c} 18$ と $F_{c} 9$ それぞれのグループに対してせん断終局強度を安全側に評価 する観点から $\beta_{L}$ の下限值を定めると, Fig. 11 (c) の実線のように $F_{c} 18$ で $\beta_{L}=1.27, F_{c} 9$ で $\beta_{L}=0$ となる。ここで， $F_{c}$ を $\sigma_{B}$ に読み替え， $\sigma_{B}$ と $\beta_{L}$ の関係を直線回帰すると(11) 式が得られる。

$$
\beta_{L}=\frac{1.27}{9} \sigma_{B}-1.27
$$

$\sigma_{B}$ が $9 \mathrm{~N} / \mathrm{mm}^{2}$ と $18 \mathrm{~N} / \mathrm{mm}^{2}$ の場合を一例として, (10),(11) 式およ び(3) 式による $b^{\prime} / b-k_{c s}$ 関係を Fig.11(d)にそれぞれ示す。

\section{3 提案式の検証}

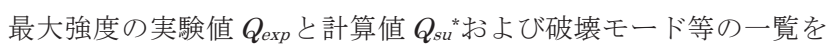
Table9， $Q_{\exp }$ と $Q_{s u}{ }^{*}$ の比較を Fig.12にそれぞれ示す。実験における 破壊モードを明確に判別するのは難しいが，本論では最大強度時に 鉄骨フランジに沿ったせん断付着ひび割れを生じているものをせん 断付着破壞 SB，それ以外で曲げ破壊とは異なるせん断破壊を $\mathrm{S}$ と 判定した。なお，実験における破壊モードが $\mathrm{S}$ の場合は ${ }_{r c} Q_{s u 1}$ を用 いて $Q_{s u}{ }^{*}$ を算定し, SB の場合は ${ }_{r c} Q_{s u 2}$ を用いて $Q_{s u}{ }^{*}$ を算定した。計 算における破壊モードは, ${ }_{r c} Q_{s u 1}<{ }_{r c} Q_{s u 2}$ の場合は $\mathrm{S},{ }_{r c} Q_{s u 1}>_{r c} Q_{s u 2}$ の 場合は $\mathrm{SB},{ }_{r c} Q_{s u 1}={ }_{r c} Q_{s u 2}$ の場合は $\mathrm{S} / \mathrm{SB}$ と示した。

充腹型 $\mathrm{SRC}$ 部材について, $Q_{e x p} / Q_{s u}{ }^{*}$ の平均值は 1.06 , 変動係数 は $3.0 \%$, 不合格率は $0 \%$ となった。一方, 非充腹型 SRC 部材につ いて, $Q_{e x p} / Q_{s u}{ }^{*}$ の平均值は 1.12 , 変動係数は $9.6 \%$, 不合格率は $15.4 \%$ となった。全試験体については, $Q_{\exp } / Q_{\text {su }}{ }^{*}$ の平均值は 1.10 , 変動係 数は $8.4 \%$, 不合格率は $10.0 \%$ となった。提案式による計算值は耐

\begin{tabular}{|c|c|c|c|c|c|c|c|c|c|c|c|c|c|}
\hline \multirow{2}{*}{ Specimen } & \multirow{2}{*}{$F_{c}$} & \multirow{2}{*}{$Q_{\exp }$} & \multirow{2}{*}{$Q_{s u}$} & \multirow{2}{*}{$Q_{m u}$} & \multirow{2}{*}{$Q_{s u}^{*}$} & \multirow{2}{*}{${ }_{r c} Q_{s u 1}$} & \multirow{2}{*}{$k_{c s}$} & \multirow{2}{*}{${ }_{r c} Q_{\text {su } 2}$} & \multirow{2}{*}{${ }_{s} \boldsymbol{Q}_{s u}$} & \multirow{2}{*}{$Q_{e x p} / Q_{s u}$} & \multirow{2}{*}{$Q_{\exp } / Q_{s u}{ }^{*}$} & \multicolumn{2}{|c|}{ Failure mode } \\
\hline & & & & & & & & & & & & Exp. & Cal. \\
\hline C18FC1515 & 18 & 362 & 379 & 403 & 349 & 199 & 0.72 & 184 & 165 & 0.96 & 1.04 & SB & SB \\
\hline C09FC1530 & 9 & 310 & 347 & 359 & 303 & 133 & 0.33 & 140 & 163 & 0.89 & 1.02 & SB & $\mathrm{S}$ \\
\hline C09FC1515 & 9 & 322 & 347 & 359 & 303 & 133 & 0.33 & 140 & 163 & 0.93 & 1.06 & SB & $\mathrm{S}$ \\
\hline C18FC1015 & 18 & 475 & 428 & 625 & 434 & 242 & 0.73 & 215 & 219 & 1.11 & 1.09 & SB & SB \\
\hline C09FC1030 & 9 & 419 & 376 & 561 & 382 & 173 & 0.42 & 163 & 219 & 1.11 & 1.10 & SB & SB \\
\hline C18FH1515 & 18 & 379 & 366 & 425 & 354 & 225 & 1.00 & 225 & 129 & 1.04 & 1.07 & SB & S/SB \\
\hline C09FH1530 & 9 & 275 & 325 & 322 & 269 & 144 & 0.43 & 140 & 129 & 0.85 & 1.02 & SB & SB \\
\hline C18BC1515 & 18 & 197 & 228 & 380 & 199 & 200 & 0.71 & 182 & 17 & 0.86 & 0.99 & SB & SB \\
\hline C09BC 1530 & 9 & 152 & 206 & 333 & 157 & 160 & 0.35 & 141 & 16 & 0.74 & 0.97 & SB & SB \\
\hline C09BC 1515 & 9 & 159 & 206 & 346 & 157 & 160 & 0.35 & 141 & 16 & 0.77 & 1.01 & SB & SB \\
\hline C18BC1015 & 18 & 258 & 278 & 584 & 242 & 245 & 0.74 & 217 & 25 & 0.93 & 1.07 & SB & SB \\
\hline C09BC 1030 & 9 & 240 & 249 & 490 & 186 & 203 & 0.41 & 162 & 24 & 0.96 & 1.29 & SB & SB \\
\hline C18BH1515 & 18 & 284 & 249 & 386 & 248 & 227 & 1.00 & 226 & 22 & 1.14 & 1.15 & SB & SB \\
\hline C09BH1530 & 9 & 183 & 195 & 257 & 152 & 149 & 0.32 & 130 & 22 & 0.94 & 1.20 & $\mathrm{SB}$ & $\mathrm{SB}$ \\
\hline B182032 & 18 & 134 & 133 & 229 & 103 & 92 & 0.59 & 83 & 20 & 1.01 & 1.30 & SB & SB \\
\hline B183232 & 18 & 132 & 142 & 229 & 116 & 101 & 0.59 & 96 & 20 & 0.93 & 1.14 & SB & SB \\
\hline B183257 & 18 & 141 & 140 & 198 & 118 & 101 & 0.79 & 105 & 17 & 1.01 & 1.19 & $\mathrm{~S}$ & $\mathrm{~S}$ \\
\hline В092032 & 9 & 97 & 119 & 224 & 84 & 66 & 0.29 & 64 & 20 & 0.81 & 1.15 & SB & SB \\
\hline B093232 & 9 & 98 & 128 & 224 & 95 & 70 & 0.28 & 75 & 20 & 0.76 & 1.03 & SB & $\mathrm{S}$ \\
\hline B093257 & 9 & 95 & 125 & 192 & 85 & 68 & 0.27 & 70 & 17 & 0.76 & 1.12 & $\mathrm{~S}$ & $\mathrm{~S}$ \\
\hline
\end{tabular}

Table 9 Observed and calculated maximum strength

$Q_{m u}:$ Ultimate flexural strength, SB:Shear bond failure, S:Shear failure 
(a) Full web type

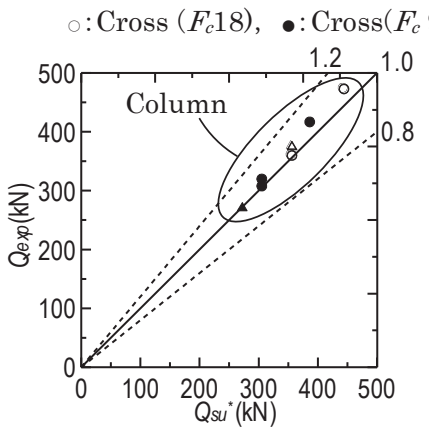

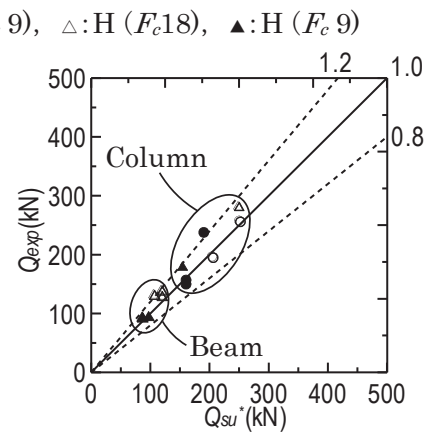

(b) Open web type

Fig.12 Comparisons between observed and calculated values

震診断基準式よりもせん断強度を過大に評価せず，ばらつきを小さ く評価できている。

実験と計算で破壊モードが一致していない試験体もあるが, ${ }_{r c} Q_{s u 1}$ と ${ }_{r c} Q_{s u 2}$ の計算值の差は小さく, 実験でせん断付着破壞と判定した 試験体でもせん断付着ひび割れ以外の斜めひび割れを生じており, 本実験は SB で決まる実強度と S で決まる実強度が近い值の試験体 であったものと思われる。なお, 耐震診断等において SRC 部材の せん断終局強度を評価するには, ${ }_{r c} Q_{s u 1}$ と ${ }_{r c} Q_{s u 2}$ の小さい方の值を ${ }_{r c} Q_{u}$ とし，（5）式を用いて評価すればよいと考える。

\section{6. まとめ}

本研究によって得られた結論を以下にまとめる。

1）いずれの $\mathrm{SRC}$ 柱とも強軸鉄骨のフランジに沿った位置でせん断 付着破壊を生じる破壊形式となった。コンクリート強度に関わら ず, 充腹型 SRC 柱では紡錘形, 非充腹型 SRC 柱ではスリップ 型の履歴ループとなり, コンクリート強度が小さい場合, 柱のせ ん断強度は小さくなるが, 限界変形角は大きくなった。

2）せん断破壊する低強度コンクリートの RC 柱は, 設計で想定され た軸力比より実際の軸力比が大きくなることで脆性的な挙動を 示すことが明らかにされているのに対して, SRC 柱は鉄骨が圧 縮軸力を負担するため, 低強度コンクリートであっても RC 柱ほ ど脆性的ではなく, 優れた変形能力と軸力保持能力を有していた。

3）非充腹型 SRC 梁は $b^{\prime} / b$ の大さによって最大強度時のひび割れ 発生状況に違いが見られたが, いずれの試験体ともにスリップ型 の履歴ループとなった。コンクリート強度や $b^{\prime} / b$ の大きさに関 わらず, 最終的には鉄骨フランジあるいは主筋に沿った位置でせ 儿断付着破壞を生じており, $b^{\prime} / b$ が大きい場合は限界変形角が 大きくなった。

4）SRC 耐震診断式によるせん断終局強度は, 全試験体を通して実 験值が計算值を下回る場合が多く, 特に, コンクリート圧縮強度 の適用範囲を下回る試験体に限ると 1 体を除き他の全ての試験 体は危険側に評価された。

5）低強度コンクリートに対応できるせん断終局強度式を提案した。 提案式は耐震診断基準式よりばらつきが小さくなり, 実験值をほ ぼ安全側に評価した。

\section{謝辞}

本研究は JSPS 科研費 JP16H04458（代表研究者：荒木秀夫）の 助成を受けたものです。ここに記して謝意を表します。
参考文献

1) Japan Concrete Institute, Chugoku Branch: Tei kyoudo concrete ni kansuru tokubetsu kenkyu iin kai houkoku syo, 2013.3 (in Japanese) 日本コンクリート工学会中国支部：低強度コンクリートに関する特別研究 委員会報告書(2013), 2013.3

2) Taishin kaisyuu hou kenkyuu kai: Kaisei kentikubutsu no taishin kaisyuu no sokushin ni kansuru houritsu • dou sekourei tou no kaisetsu, 2013.12 (in Japanese)

耐震改修法研究会 : 改正 建築物の耐震改修の促進に関寸る法律・同施工令 等の解説, 2013.12

3) Wakabayashi M., Minami K., Tani S. and Hirano M.: Shin kenchiku gaku taikei 42 gousei kouzou no setsukei, 1995.10 (in Japanese) 若林實, 南宏一, 谷資信, 平野道勝: 新建築学体系 42 合成構造の設計, 1995.10

4) The Japanese Building Disaster Prevention Association: Kison tetsukotsu tetsukin concrete zou tatemono no taishin shindan kizyun dou kaisetsu, 2009.12 (in Japanese)

日本建築防災協会 : 既存鉄骨鉄筋コンクリート造建築物の而震診断基準同 解説, 2009.12

5) Architectural Institute of Japan: AIJ Standard for Structural Calculation of Steel Reinforced Concrete Structures (The third edition), 1975.11 (in Japanese)

日本建築学会: 鉄骨鉄筋コンクリート構造計算規準・同解説(第 3 版), 1975.11

6) Yasojima A., Araki H., Matsui T. and Taniguchi H.: Evaluation of Shear Strength for Low Strength Concrete Members, AIJ Journal of Technology and Design, Vol.16, No.32, pp.139-144, 2010.2 (in Japanese) 八十島章，荒木秀夫，松井剛，谷口博亮：低強度コンクリート部材のせん 断性能評価, 日本建築学会技術報告集, 第 16 巻, 第 32 号, pp.139-144, 2010.2

7) Li L., Tsuda K. and Matsui C.: Deformation Capacity and Axial Load Limit of Steel Reinforced Concrete Columns Subjected to Axial and Flexural Loading, Journal of Structural and Construction Engineering (Transactions of AIJ), No.524, pp.133-140, 1999.10 (in Japanese) 李麗, 津田恵吾, 松井千秋 : 軸圧縮力と曲げを受ける鉄骨鉄筋コンクリー 卜柱の変形性能と軸力制限值, 日本建築学会構造系論文集, 第 524 号, pp.133-140, 1999.10

8) Neguchi M., Kawakami K., Takatsuki Y. and Minami k.: 10N/mm² kyu no teikyoudo concrete wo mochiita RC hashira no sendan hakai seizyo, Proceedings of the Japan concrete institute, Vol.30, No.3, pp.1129-1134, 2008.6 (in Japanese)

根口百世, 川上裕佳, 高月行治, 南宏一: $10 \mathrm{~N} / \mathrm{mm}^{2}$ 級の低強度コンクリー 卜を用いた RC 柱のせん断破壊性状, コンクリート工学年次論文集, Vol.30, No.3, pp.1129-1134, 2008.6

9) Sakata M., Sakai J., Tanaka T. and Higaki N.: Elastic-Plastic Behavior of Steel Reinforced Concrete Column with Encase Cruciform Steel, Journal of Structural Engineering, Vol.57B, pp.535-542, 2011.3 (in Japanese)

坂田学, 堺純一, 田中照久, 檜垣直也 : 十字鉄骨を内臓した鉄骨鉄筋コン クリート部材の弾塑性性状に関寸る研究, 構造工学論文集, Vol.57B, pp.535-542, 2011.3

10) Architectural Institute of Japan: AIJ Standard for Structural Calculation of Steel Reinforced Concrete Structures (The sixth edition), 2014.1 (in Japanese)

日本建築学会:鉄骨鉄筋コンクリート構造計算規準・同解説(第 6 版), 2014.1

11) Wakabayashi M. and Minami k.: Shear Strength of Steel Reinforced Concrete (SRC) Columns under Constant Axial Load and Well-defined Alternately Repeated Bending and Shear, Concrete Journal, Vol.13, No.3, pp.1-17, 1975.3 (in Japanese)

若林實，南宏一：一定軸力と確定的な繰返し曲げせ九断力を受ける鉄骨鉄 筋コンクリート柱のせん断強度に関する実験的研究, コンクリート工学, Vol.13, No.3, pp.1-17, 1975.3

12) Doi M. and Shohara R.: Study on the Design Formula to Estimate Shear Strength of SRC Members Based on the Theory of Plasticity, Journal of Structural and Construction Engineering (Transactions of AIJ), No.516, pp.151-158, 1999.2 (in Japanese)

土井希祐, 称原良一: SRC 部材の塑性理論に基づくせん断設計式の検討, 日本建築学会構造系論文集, 第 516 号, pp.151-158, 1999.2 


\title{
ULTIMATE SHEAR STRENGTH OF EXISTING STEEL REINFORCED CONCRETE MEMBERS WITH LOW-STRENGTH CONCRETE
}

\author{
KJU KJU NWE ${ }^{* 1}$, Kazushi SADASUE ${ }^{* 2}$ and Hideo ARAKI ${ }^{* 3}$ \\ ${ }^{* 1}$ Grad. Student, Major in Intelligent Structure and Functional Science, Hiroshima Institute of Technology, M.Eng. \\ ${ }^{* 2}$ Assoc. Prof., Dept. of Architectural Eng., Faculty of Eng., Hiroshima Institute of Technology, Dr.Eng. \\ ${ }^{* 3}$ Prof., Dept. of Architectural Eng., Faculty of Eng., Hiroshima Institute of Technology, Dr.Eng.
}

In this experimental study, 14 test columns and 6 test beams were prepared. Considered parameters were steel type, concrete strength, shear span ratio and axial load level. In order to mitigate disaster, seismic evaluation and retrofit for existing concrete buildings have been extensive in Japan after the 1995 Hyogoken-Nanbu earthquake. According to the some reports of seismic evaluation for existing concrete buildings, it is often reported that concrete buildings have very low concrete strength.

In this paper, shear strength of SRC members with low-strength concrete are investigated through the seismic loading tests. We focused on the existing high-rise building of SRC members, such as, column and beam of low-strength concrete. In here, low-strength concrete means is lower than the applicable lower limit $\left(\sigma_{B} \geq 13.5 \mathrm{~N} / \mathrm{mm}^{2}\right)$ of the existing seismic performance evaluation standard.

In column tests, when the maximum strength was observed, the shear-bond cracks were occurred along the steel flange position. Regardless of the concrete strength, the spindle-type hysteresis characteristic was shown for the full web type SRC column, and the slip-type hysteretic characteristic was shown for the open web type SRC column. Moreover, when the concrete strength is low, the shear strength of the columns decreased, but the critical deformation angle increases. From the previous researches result, $\mathrm{RC}$ column with low-strength concrete showed brittle behavior as the axial force became larger than designed load. On the other hand, SRC column is not as brittle as RC column because steel frame could support the compressive axial force. Even though low strength concrete, it was confirmed that SRC column has excellent deformation capacity and axial force retaining ability.

From beam tests, differences in the crack battens at the maximum strength were observed depending on the size of $b \% b$. When the maximum strength was observed, the shear-bond cracks were occurred along the steel flange position, which the specimen of steel had large width flange. But, the slip-type hysteretic characteristic was observed for all beam specimens. Eventually, regardless of the concrete strength and size of $b \% b$, the shear-bond cracks occurred at the position along the steel flange or main rebar. But, when $b \% b$ was large, the critical deformations became increased.

According to the test results, it is found that the ultimate shear strength of low-strength concrete's SRC member could not be evaluated using the present evaluation method recommended by The Japanese Building Disaster Prevention Association (JBDPA). In particular, for specimens with low-strength concrete, the maximum strength of the specimens were underestimate, except for one specimen.

As the result of proposing the ultimate shear strength equation corresponding to the SRC member of low-strength concrete, and verifying the experiment result, the calculated value by the proposed equation is overly evaluated with the shear strength as compared with the SRC seismic evaluation criterion equation. It was found that the experimental values can be evaluated roughly and reasonably by the proposed method. 